Article

\title{
Japan's Climate Change Discourse: Toward Climate Securitisation?
}

\author{
Florentine Koppenborg ${ }^{1, *}$ and Ulv Hanssen ${ }^{2}$ \\ ${ }^{1}$ Bavarian School of Public Policy, Technical University Munich, Germany; E-Mail: florentine.koppenborg@hfp.tum.de \\ 2 Faculty of Law, Soka University, Japan; E-Mail: hanssen@soka.ac.jp \\ * Corresponding author
}

Submitted: 28 April 2021 | Accepted: 8 July 2021 | Published: 22 October 2021

\begin{abstract}
This article situates Japan in the international climate security debate by analysing competing climate change discourses. In 2020, for the first time, the Japanese Ministry of the Environment included the term "climate crisis" (kikō kiki) in its annual white paper, and the Japanese parliament adopted a "climate emergency declaration" (kikō hijō jitai sengen). Does this mean that Japan's climate discourse is turning toward the securitisation of climate change? Drawing on securitisation theory, this article investigates whether we are seeing the emergence of a climate change securitisation discourse that treats climate change as a security issue rather than a conventional political issue. The analysis focuses on different stakeholders in Japan's climate policy: the Japanese Ministry of the Environment, the Ministry of Economy, Trade, and Industry, the Ministry of Foreign Affairs, the parliament, the Cabinet, and sub- and non-state actors. Through a discourse analysis of ministry white papers and publications by other stakeholders, the article identifies a burgeoning securitisation discourse that challenges, albeit moderately, the status quo of incrementalism and inaction in Japan's climate policy. This article further highlights Japan's position in the rapidly evolving global debate on the urgency of climate action and provides explanations for apparent changes and continuities in Japan's climate change discourse.
\end{abstract}

\section{Keywords}

bureaucratic politics; civil society; climate; crisis; discourse; emergency; Japan; securitisation

\section{Issue}

This article is part of the issue "Climate Change and Security" edited by Yasuko Kameyama (National Institute for Environmental Studies, Japan) and Yukari Takamura (University of Tokyo, Japan).

(C) 2021 by the authors; licensee Cogitatio (Lisbon, Portugal). This article is licensed under a Creative Commons Attribution 4.0 International License (CC BY).

\section{Introduction}

Climate change is undeniably one of the most pressing issues of our time. Global warming "will amplify existing risks and create new risks for natural and human systems" (Intergovernmental Panel on Climate Change, 2014 , p. 13). The international community adopted the Paris Agreement in 2015 to limit "the increase in the global average temperature to well below $2{ }^{\circ} \mathrm{C}$ above pre-industrial levels and pursuing efforts to limit the temperature increase to $1.5{ }^{\circ} \mathrm{C}$ above pre-industrial levels" (UN, 2015, p. 3):

[L]imiting global warming to $1.5^{\circ} \mathrm{C}$, compared with $2{ }^{\circ} \mathrm{C}$, could reduce the number of people both exposed to climate-related risks and susceptible to poverty by up to several hundred million by 2050 [and] may reduce the proportion of the world population exposed to a climate change-induced increase in water stress by up to $50 \%$. (Intergovernmental Panel on Climate Change, 2018, p. 9)

Japan is already experiencing the impacts of climate change. The Global Climate Risk Index, which looks at losses and fatalities stemming from extreme weather events, ranked Japan as the most affected country in the world in 2018 and fourth-most in 2019 (Eckstein et al., 2019, 2021). In 2018, a heatwave that killed more than 1500 people "could not have happened without humaninduced global warming" (Imada et al., 2019). Given the 
increasing impact on people's livelihoods, this article investigates to what extent Japan's climate change discourse addresses global warming as a security challenge.

Security-related climate change discourse can be further divided into two discourses: 1) a "conflict" discourse that focuses on the link between climate change and resource scarcity, which can lead to conflict and consequently threaten state stability, and 2) a "security" discourse that highlights the link between climate change and human security-particularly threats to people's livelihoods (Busby, 2019; Detraz \& Betsill, 2009). The conflict-centred discourse's focus on military responses has been criticised as detrimental to efforts aimed at limiting climate change (Detraz \& Betsill, 2009; Elliott, 2012; McDonald, 2013).

In 2007, the impact of climate change on peace and security was discussed for the first time in the UN Security Council. Japan's representative showed little enthusiasm for linking climate and security (UN Security Council, 2007). This reflected how security is conceptualised in Japan, as either "national security" (anzen hoshō) or "comprehensive security" (sōgō anzen hoshō). The Ministry of Defence, in charge of national security, does not deem climate change a relevant issue concerning military matters. Although the Ministry of Foreign Affairs (MOFA) adopts the broader notion of human security, it has thus far refrained from linking it to climate change (Kameyama \& Ono, 2021). Occurrences of securitisation in Japan's foreign and defence policy are limited to traditional security issues such as China's military rise (Schulze, 2016) and North Korea's nuclear development and past abductions of Japanese citizens (Hagström \& Hanssen, 2015). Since "climate conflict" discourse is largely absent in Japan, this article focuses on "climate security" discourse.

For decades, UN organisations and climate activists have been trying to securitise climate change, i.e., make policymakers treat the issue with the urgency of a security threat (de Wilde, 2008; McDonald, 2013). Recent examples include Greta Thunberg (2019a), who famously warned at the World Economic Forum that "Our house is on fire," as well as UN Secretary-General António Guterres (2019), who has stressed that "if we don't urgently change our ways of life, we jeopardise life itself."

In 2019, a wave of "climate and environmental emergency" declarations began sweeping the globe. By October 2020, 1,788 jurisdictions in 31 countries had declared climate emergencies, covering more than 820 million citizens (Climate Emergency Declaration Campaign, 2020). Further signalling a climate security discourse gaining traction are "climate crisis" statements, for example in the EU's updated 2020 Nationally Determined Contribution under the Paris Agreement (EU, 2020) and in US President Joe Biden's (2021) remarks on "Climate Day" on day seven of his presidency.

In Japan, climate change has hitherto been "framed as an economic as well as an energy problem" (Kameyama, 2017, p. 167). However, the Ministry of the
Environment (MOE) included the term "climate crisis" (kikō kiki) in its annual white paper in 2020 (MOE, 2020). It attracted media attention for being the first governmental publication to use the term "climate crisis." Later that year, the Japanese parliament declared a "climate emergency" (Diet of Japan, 2020).

The recent emergence of security-related climate change rhetoric in Japan has not yet been covered in the academic literature. Since the first climate emergency declarations emerged in Japan in late 2019, signalling a potential turning point in Japan's climate change discourse, the in-depth analysis of recent documents focuses on the short yet crucial period from late 2019 to early 2021.

This article poses the following research question: To what extent is Japan addressing climate change as a security threat? Put differently, does the use of the terms "climate emergency" and "climate crisis" signal a discursive shift toward climate securitisation in Japan's climate policy?

\subsection{Japan's Climate Change Policy and Discourse}

Japan's climate policy has fluctuated between the roles of leader and laggard. This process has been "closely linked to the struggle between the often competing norms of economic growth, energy efficiency, international contribution, and environmental protection" (Hattori, 2007, p. 75). Key actors shaping Japan's domestic climate policy are the Ministry of Economy Trade and Industry (METI) and the MOE, while the government largely takes a back-seat role. Whereas the METI promotes economic growth and energy efficiency, the MOE is pushing for stronger environmental protection including climate action. The power balance between these two usually favours the METI and the (heavy) industries it represents (Sofer, 2016; Watanabe, 2011).

A noteworthy exception to this dynamic was the second half of the 1990s when Japan positioned itself as a climate leader and hosted international climate negotiations. In this context, the MOFA became involved in climate policy debates and the Liberal Democratic Party Prime Minister Ryūtarō Hashimoto (1996-1998) pushed for an ambitious climate policy, including the promotion of greater awareness of the "global warming problem." Against this backdrop, the notion of environmental protection and an international contribution outweighed concerns about the economic costs of climate change mitigation (Hattori, 2007). Support by the MOFA and the prime minister tipped the scale in the inter-ministerial competition between the METI and the MOE in favour of the position advocated by the MOE (Kameyama, 2002, 2017; Tiberghien \& Schreurs, 2010; Watanabe, 2011).

After the US withdrew from the Kyoto Protocol in 2001, raising concerns about the international competitiveness of Japan's industry, the balance of power shifted back to the METI-sponsored discourse on climate policy in which "the cost side" of mitigation was 
emphasised (Kameyama, 2017, p. 170). Following a UK proposal to include climate security in the UN Security Council agenda in 2007, the MOE published a Report on Climate Security. However, it quickly dropped the term, arguably due to climate security being outside the scope of Japanese conceptions of security and to avoid impinging on the security responsibilities of the Ministry of Defence (Kameyama \& Ono, 2021).

The shift from leader to laggard in the 2000s was exacerbated after the Fukushima Daiichi nuclear accident in 2011. Successive administrations under Prime Minister Shinzō Abe (2012-2020) were characterised by the "prioritisation of economic growth over environmental issues, and hence the greater bureaucratic influence of the METI over the MOE" (Incerti \& Lipscy, 2018, p. 632). While the government pushed for nuclear reactor restarts in the name of climate change mitigation, it had, in fact, lost power to implement its nuclear energy policy (Koppenborg, 2021), which led to a significant increase in Japan's reliance on coal to replace discontinued nuclear power plants.

Internationally, Japan was criticised for submitting unambitious emissions reduction targets for the 2015 Paris Climate Summit (Kameyama, 2017). "Unwilling to give up Japan's status as an important contributor to global climate change efforts" (Incerti \& Lipscy, 2018 , p. 629), Japan was under pressure to present an improved climate strategy when it hosted the G20 in 2019. Japan's long-term strategy under the Paris Agreement "for the first time in the history of Japanese official decisions on climate change...declared that reducing GHG [greenhouse gas] emissions would stimulate economic growth rather than viewing it only as an economic burden" (Kameyama, 2021, p. 77). Hence, toward the end of Abe's term, there were apparent efforts to reconcile the focus on economic growth with climate change mitigation efforts and the desire to exhibit international leadership.

Abe's successor, Yoshihide Suga, has also expressed his intention for Japan to assume an international climate leadership role. Following climate neutrality announcements by several countries, in 2020, Suga announced the goal to achieve carbon neutrality by 2050 . At the time of writing, the Suga administration is in the process of hammering out revised emissions reduction targets for the Climate Summit in November 2021.

Interestingly, in the past decade, cities and non-state actors have emerged as a potential force for change in Japan's climate policy. Cities with ambitious climate action plans, with the Tokyo Metropolitan Government as the most famous example, became dynamic contrasts to Japan's otherwise lacklustre climate policy (Koppenborg, 2018; Sofer, 2016). After the Paris Agreement, many non-state actors in Japan began setting more ambitious targets for greenhouse gas reductions than the government (Kameyama, 2021).

What is driving changes in Japan's otherwise METIdominated climate policy and discourse? Overall, "inter- national climate politics are one of the largest factors affecting Japan's climate policy" as Japan seeks to contribute to international climate action (Watanabe, 2011, p. 28). If the MOFA and the government, most notably the prime minister, begin framing climate action as part of Japan's international contribution, it can shift the balance of power in favour of the MOE's more ambitious climate policy stance and introduce a reframing of climate change. In addition, Japan's involvement with the G7/8 and the position of other states, most notably the US, can impact Japan's climate policy (Kameyama, 2017; Tiberghien \& Schreurs, 2010). Furthermore, the recent rise of Japanese non-state climate action is partly influenced by international movements in the context of the 2015 Paris Agreement negotiations (Kameyama, 2021).

Regarding the impetus for the adoption of "climate security" language in Japan in recent years, we expect that it either came from international climate politics or local and non-state actors in Japan. We further suppose that the climate change discourse put forward by the METI will remain hegemonic unless the MOE's climate crisis language gains support from other ministries and the government, most importantly the prime minister.

To assess a potential shift in Japan's climate-change discourse, this article draws on securitisation theory and discourse analysis, outlined in the following section. An analysis of Japan's climate discourse should include the ministries involved, i.e., the MOE, the METI, and the MOFA, as well as other stakeholders, including the prime minister and other Liberal Democratic Party power brokers, cities, and non-state actors. The analysis first focuses on the main ministries involved, subsequently broadens the scope to include other Japanese stakeholders, and then situates Japan's climate change discourse in the literature on Japan's climate policy and discourse. Finally, it discusses potential explanations for change.

\section{Securitisation Theory and Discourse Analysis}

Securitisation is a concept developed by the so-called Copenhagen School in the late 1990s (Buzan et al., 1998, p. 26). More recently, the environment as a study domain has attracted the attention of securitisation scholars (Balzacq et al., 2016). Securitisation can be thought of as the elevation of an issue from the sphere of politics to the sphere of security, i.e., the construction of a security issue. When an issue is securitised, it is deemed so important that extraordinary measures must be taken immediately to ensure the survival of a referent object-in our case, the Japanese nation. Securitisation is carried out by one or more securitising actors who try to convince a relevant audience about the existential threat posed by a specific issue and the need to undertake extraordinary measures (Buzan et al., 1998, pp. 23-24). In this case, the relevant audience are the abovementioned key climate policy actors.

Discourses can be thought of as temporarily fixed constellations of meaning in which signifiers (words, 
objects, and actions) are given specific meaning by their linkages to other signifiers. Signifiers can thus have widely different meanings in different discourses depending on which other signifiers they are placed in relation to. Drawing on an example by Howarth (2000, p. 9), an ecological discourse might conceive of a "forest" as "an object of intrinsic natural beauty," whereas a capitalist discourse might frame the same forest as "an obstacle to the building of a motorway." In the former discourse, the signifiers "forest" and "beauty" are tied together, while in the latter, the "forest" might be seen as a "business opportunity." Needless to say, these two discourses structure widely different understandings of the forest and what should be done with it (preservation/destruction). It is therefore important to investigate word linkages in the text under analysis.

We should point out that we do not imply that discourses directly cause action. But we do argue that powerful discourses have enabling and constraining effects on actors through their ability to render certain practices logical and others illogical (Doty, 1993). This means that the subsequent discourse analysis will not be able to predict the extent to which Japan's climate policy will change, but the discovery of a burgeoning securitisation discourse would demonstrate that the "conditions of possibility" (Weldes \& Saco, 1996, p. 395) for serious climate action have materialised.

Since we are interested in examining the extent to which climate change is being securitised in Japan, it is necessary to clarify what a securitising discourse looks like. A minimum requirement is the framing of climate change as an existential threat that requires extraordinary measures. However, we would also suggest that to speak of a full-fledged securitising discourse, antagonism against the status quo must also be present in some form or another. This is because a securitising discourse is by nature status quo challenging as it seeks to radically revise conventional wisdom about what the main security threats are.

In the following, we conceptualise three degrees of securitisation: non-securitisation, moderate securitisation, and strong securitisation. The first refers to discourses that altogether refrain from framing climate change as an existential threat. The second points to discourses that frame climate change as an existential threat but are less clear about extraordinary measures and refrain from using antagonistic language toward climate change's culprits. US President Joe Biden (2021, para. 9), for example, has talked about the need to "confront the existential threat of climate change," but he does not single out climate perpetrators. The third signifies discourses that both frame climate change as an existential threat requiring extraordinary measures and exhibit antagonism toward actors fuelling climate change, e.g., oil and gas companies, indifferent or slow-moving politicians, climate change deniers, etc. The speech by activist Greta Thunberg at the 2019 UN Climate Action Summit is a good example: "People are suffering. People are dying. Entire ecosystems are collapsing. We are at the beginning of a mass extinction, and all you can talk about is money and fairy tales of eternal economic growth. How dare you!" (Thunberg, 2019b). The statements by UN SecretaryGeneral António Guterres (2019) at the same event are not as combative as Greta Thunberg's, but they clearly condemn activities that further fuel climate change: "Is it common sense to give trillions in hard-earned taxpayers' money to the fossil fuel industry to boost hurricanes, spread tropical diseases, and heighten conflict?" The antagonistic warnings by Greta Thunberg and António Guterres represent strong securitisation while US President Joe Biden's statement represents moderate securitisation language due to the lack of antagonism.

To examine whether Japan is moving toward securitisation of climate change, it is necessary to analyse the major competing climate change discourses in Japan and the power balance between them. The analysis draws on numerous written documents: ministries' annual papers, government members' statements in the Japanese parliament (Diet of Japan), the prime minister's speeches at international climate conferences, cities' emergency declarations, and climate NGOs' statements. In the following analysis, we will identify how these documents place climate change in relation to other signifiers and thereby sketch out the extent of securitisation in Japan's climate change discourse.

\section{Discourse Analysis}

The simplest method to discern differences between relevant ministries' attitudes toward climate change is a word count of key terms. We have excluded the Ministry of Defence from the discourse analysis because it is not involved in climate policymaking and because its 2020 white paper hardly contains any references to climate change. As seen in Table 1, unlike the MOE, neither the METI nor the MOFA has adopted the term "climate crisis" in their white papers. While these numbers demonstrate whether these ministries have adopted a climate crisis framing or not, they do not reveal the specific ways in which the ministries articulate different discourses on climate change. The following discourse analysis seeks to show how the MOE, the METI, and the MOFA frame climate change in their 2020 white papers.

\subsection{METI, MOE, and MOFA White Paper Analysis}

\subsubsection{Crisis Framing}

The natural starting point for a climate change discourse analysis is to look at how the respective white papers incorporate the term "climate change" into their discourses. We can label the MOE discourse as a securitisation discourse because it unmistakably frames climate change as an existential threat "that shakes the foundation of existence for humanity and all living beings" 
Table 1. Appearance of key terms in the ministries' annual papers.

\begin{tabular}{lrrr}
\hline Keywords (climate concerns) & MOE & METI & MOFA \\
\hline Climate crisis (kikō kiki) & 5 & 0 & 0 \\
Climate change (kikō hendō) & 495 & 49 & 81 \\
Survival (seizon) & 10 & 0 & 6 \\
Societal change (shakai henkaku) & 96 & 0 & 1 \\
Decarbonisation (datsu-tanso) & 162 & 60 & 4 \\
\hline
\end{tabular}

Note: Derived from a keyword search in the METI (2020), the MOE (2020), and the MOFA (2020).

(MOE, 2020, p. 20). The crisis framing is clearly inspired by international developments. The first reference to "climate crisis" reads as follows:

Among the world's main leaders, there is a growing sense of risk. Furthermore, on the grassroots level, particularly overseas, there are demonstrations by young people, demanding countermeasures against climate change, as well as a growing movement by local governments to declare a "climate crisis," so now we are living in an age that can be described as a "climate crisis" (MOE, 2020, p. 3).

Almost the entire first chapter is dedicated to the negative effects of climate change. To drive home the fact that climate change has real-life consequences and is an existential threat for everyone, pages six to nine are devoted to natural disasters that have struck Japan and other countries in recent years. Each disaster is described in detail, including the number of deaths, buildings destroyed, and estimated costs. This is followed by a section that spells out the scientific relation between climate change and these disasters (MOE, 2020, pp. 9-18). The MOE paper links climate change to different negatively loaded signifiers, such as disasters, extreme rain and drought, rising sea levels, the spread of infectious diseases, crop failure, extinction of wildlife, and disruptions of human societies. Hence, the meaning that is given to climate change in the MOE discourse is that of an all-encompassing and potentially all-ending threat that must take precedence over all other threats.

In contrast, the METI paper makes no mention of a "climate crisis," but the paper does warn of two crises of a radically different nature (METI, 2020, pp. 323-327): 1) a hypothetical "supply crisis," in which Japan's traditional oil suppliers are no longer able or willing to supply Japan due to unforeseen emergencies and 2) a "domestic crisis," in which natural disasters damage oil and gas stockpiles. To the extent that there are securitisation moves in the METI paper, these moves are limited to the securing of a steady supply of oil and gas-commodities that have adverse effects on climate change. Although the term "climate change" is used 49 times and the METI paper refers to the "climate change problem" (p. 85) and "the fight against climate change" (p. 96), the term is never followed by an explanation of the negative consequences on humans, animals, or the planet. Hence, it is left unclear to the reader exactly why climate change is a problem and why it needs to be fought.

Similarly, the MOFA diplomatic bluebook contains many references to climate change, but hardly any descriptions of its effects. While traditional security threats, such as North Korea's missiles and China's military build-up, are said to constitute a "very severe security environment" (MOFA, 2020, p. 12), no such trepidation is expressed in the passages concerning climate change. The "crisis" label is attached to several conflicts and issues, such as the "Syrian crisis" (p. 123) or the "humanitarian crisis" of refugees (p. 204), but climate change is never framed as such. Climate change is occasionally framed as a "problem" (p. 242) or a "global issue" (p. 11), but mostly qualifiers are absent. On page 11, the paper states that "the severity of natural disasters is forecast to continue to intensify with the effects of climate change." It is noteworthy that this is the only passage in the whole paper where climate change is directly linked to real-life effects. All other mentions of climate change fail to make this linkage, giving readers the impression that climate change is an abstract problem largely detached from their lives. In fact, climate change is almost always mentioned as one of many items in list-ups of problems facing the world. No prioritisation is given to climate change.

The clear causality between climate change and crisis/disaster in the MOE paper is virtually non-existent in the other papers. Since neither the MOFA nor the METI identifies climate change as a particularly threatening issue, this contributes to the framing of climate change as a non-urgent problem.

\subsubsection{Calls for Action}

The discursive difference between the white papers can also be discerned by how they suggest that climate change should be dealt with. In line with its securitising nature, the MOE white paper argues that climate change must be countered with extraordinary measures. The clearest example of this is found in the introduction. It states that to secure a liveable environment for future generations, "our traditional societal system and everyday habits of mass-production, mass-consumption, and mass-waste must be revaluated" (MOE, 2020, p. 3), i.e., a critique of the consumerist way of life. The paper also argues for the necessity of "transforming our current 
economic and societal systems and initiating a paradigm shift" (p. 35). As shown in Table 1, the term "societal change" is mentioned 96 times in the paper. By warning that climate change will lead to "grave problems for which traditional measures no longer work," the MOE follows the securitisation formula of calling for extraordinary measures "outside the normal bounds of political procedure" (Buzan et al., 1998, p. 24).

Given that the METI paper presents interruptions in Japan's fossil fuel supply, rather than climate change, as its greatest concern, it is not surprising that the most emphatic policy proposals in the paper are not related to climate change, but rather to securing a stable supply of oil, gas and coal. The METI paper calls on the Japanese government to strengthen its "resource diplomacy" (shigen gaikō; METI, 2020, p. 36) to ensure "friendly relations" with supplier nations (p. 226). In short, the clearest policy proposals in the METI paper concern the stable supply of the very commodities that are most damaging to the environment. The METI paper acknowledges climate change as a problem, but unlike the MOE's sweeping calls for action, the METI paper's suggestions are incremental, technocratic, and highly business oriented. All suggestions essentially boil down to innovation and technology, thus downplaying the MOE's calls for more radical societal change, a term that is not even mentioned in the METI paper. The paper advocates "discontinuous innovation" (hirenzoku-na inobēshon) that will create "new technologies that are completely different from those that exist in today's society" (p. 87). It also frames the effectiveness of Japan's thermal power plants as a contribution to decarbonisation. Moreover, the METI insists on the export of Japan's "cutting-edge" power plants and "clean coal technology" to these countries as a "practical climate change countermeasure" (p. 282).

The METI clearly views the struggle against climate change as a battlefield where businesses should stand at the forefront. By getting businesses to pollute less and invest in green technologies, a "virtuous cycle of environment and growth" is said to be achievable (METI, 2020, p. 94). The METI seeks to incentivise ecological business practices through "green finance promotion," or, in other words, funding of companies that invest in green technologies or take steps to reduce their carbon footprint. The definition of "green industrial activity" should not be too strict, it argues, for fear that the business community could lose its interest. In practice, this means that companies and projects become eligible for green funding if they can show that they "contribute to the transition toward improved GHG [greenhouse gas] emission reduction and low-carbon economies" (p. 93). Needless to say, such a loose standard of green funding enables a gradualist approach by the corporate sector. In sum, the measures suggested by the METI either run counter to fighting climate change (securing oil, gas, and coal), or enable incrementalism (more effective power plants, faith in the innovation of revolutionary technologies, and loose standards for green funding).
Like the METI, the MOFA calls for "business-led discontinuous innovation" that will create a "virtuous cycle of environment and growth" (MOFA, 2020, p. 215; both phrases come from Japan's 2019 long-term strategy under the Paris Agreement). The MOFA paper acknowledges that divestment from fossil fuel-related industries can be one way to mitigate climate change, but stresses that "divestment alone cannot address climate change" (p. 215). Accordingly, it holds that climate change should be fought by offering companies financial incentives to innovate green technologies (p. 215). These policies strongly resemble those in the METI paper. The paper also outlines how climate change features in Japan's foreign policy. Here, it points out Japan's USD 3 billion contribution to the Green Climate Fund, aimed at helping developing countries implement climate change mitigation measures, as well as Japan's Joint Crediting Mechanism, which allows Japan to list greenhouse gas reductions in other countries as part of its own nationally determined contribution to the Paris Agreement if it has provided these countries with low-carbon technologies. Hence, the MOFA's calls for action are largely marketbased and business-friendly. There is nothing in the paper that comes close to advocacy for extraordinary measures.

The MOFA and METI papers share an incremental, business-oriented approach and a belief in innovation in their discussion of climate change policy. They thus reject the MOE's plea for extraordinary measures, i.e., a fundamental transformation of Japan's economic, energy, and societal systems.

\subsubsection{Lack of Antagonism}

There are limits to the MOE's securitisation moves, however. This is particularly palpable in the absence of antagonistic language, i.e., no criticism of polluting industries, Japan's insufficient climate policy, or positions by competing ministries like the METI. The environmental problems in the MOE white paper appear like crimes without a perpetrator. It should be remembered that a white paper is supposed to be a representation of the government position and requires Cabinet approval for publication, so there are limits to how antagonistic a white paper can be. Nonetheless, subtle criticism of other discourses and even governmental policy is possible even in a white paper. Rear and Jones, for example, show that when neoliberal ideas began gaining traction in Japan in the 1990s and early 2000s, the white paper of the Ministry of Education, Culture, Sports, Science and Technology criticised Japan's education policy for placing "too much emphasis on conformity" and advocated "reforms to promote individualisation and diversification" (Rear \& Jones, 2013 , p. 382). This kind of critique of competing discourses and the policies they structure should be seen as a type of antagonism in the context of a white paper. Hence, the lack of even subtle antagonism means the MOE white paper must be characterised as a moderate securitisation attempt. 


\subsubsection{Competing Discourses}

In summary, we have shown that the MOE on the one hand and the METI and MOFA on the other represent two differing and often incompatible discourses on climate change. The MOE represents a moderate securitisation discourse, which sees climate change as an existential threat that requires extraordinary measures but omits mention of particular culprits. Conversely, the MOFA and particularly the METI represent a nonsecuritising, incrementalist discourse, which sees climate change as just one of many problems facing Japan and does not advocate specific countermeasures beyond technology innovation, efficiency improvements, and business incentives, while actively promoting the use of fossil fuels in the name of energy security.

\subsection{Japanese Context}

\subsubsection{A Burgeoning Climate Securitisation Discourse?}

This section examines the extent to which the moderate securitisation discourse introduced in the $2020 \mathrm{MOE}$ white paper resonates in Japan's overall climate change debate. To this end, Table 2 provides an overview of other Japanese stakeholders' climate policy frames.

Beginning with the Cabinet members, MOE Minister Junichirō Koizumi first mentioned "climate crisis" on February 25, 2020, in the Diet of Japan and has continued to do so since. By stressing that the MOE and the METI "are not enemies," he explicitly refutes antagonisms toward the METI's status quo-oriented policies. With the Diet of Japan's "climate emergency declaration," many parliamentarians have presumably adopted the climate crisis framing in 2021, but, notably, Prime Minister Suga, Foreign Minister Toshimitsu Motegi (2019-) and his predecessor Tarō Kōno (2017-2019) have not used the term "climate crisis" in the Diet of Japan (as of March 2021).

Looking at cities and NGOs, the Japan Climate Initiative, the Kiko Network, and several cities adopted climate securitisation language even before the MOE in 2020 and the Diet of Japan in 2021. A total of 40 local governments in Japan had issued climate emergency declarations by October 2020 (Climate Emergency Declaration Campaign, 2020). While Table 2 only lists the climate emergency declaration by Kamakura City, all local governments' emergency declarations can be understood as support for the securitisation move.

In sum, a moderate securitisation framing has garnered support from several Japanese cities and NGOs, the MOE, and its minister as well as the nonpartisan group of parliamentarians behind the Diet of Japan's climate emergency declaration. On the governmental level, however, the incrementalist discourse with its focus on promoting fossil fuels and on relying on future innovation is still hegemonic as it enjoys support by all major actors except the MOE and Koizumi. While the efforts of securitisation actors have led to the establishment of cli- mate securitisation as a new minor discourse, they have so far failed to garner support from the actors needed to transform it into a hegemonic one.

\subsubsection{Impetus for Adopting Climate Securitisation Language}

This section discusses where the impetus for adopting climate securitisation language has come from. Japanese climate securitisation actors refer to international trends, albeit different ones. As seen in Table 2, MOE Minister Koizumi's first reference to a "climate crisis" clearly acknowledges the phrase's foreign origins. The MOE white paper also traces the language of crisis back to world leaders, grassroots demonstrations overseas and local government action (see the second quote in Section 3.1.1). It can also be mentioned that the MOE white paper emphasises the inspirational impact Greta Thunberg's climate activism has had on millions of young people in Japan and abroad (MOE, 2020, p. 21). The Diet of Japan's climate emergency declaration similarly cited global perceptions as its impetus for action (see Table 2). The Japan Climate Initiative draws inspiration from "organisations of various non-state actors [that] are getting underway in other countries" (Japan Climate Initiative, 2018, p. 1), while Kamakura City links its own climate emergency declaration to the global trend among cities to adopt such declarations (Kamakura City Council, 2019). Japanese securitisers were clearly inspired by international climate politics.

How about the international influence on the government? US President Joe Biden has repeatedly used the term "climate crisis" since taking office in January 2021. In the Diet of Japan, Suga made his first mention of climate change only after Joe Biden was elected as US President. Both Suga and Motegi almost always mention climate change in the context of the Japan-US alliance. This suggests that their concern about climate change is mainly aimed at strengthening the Japan-US alliance. Given this focus and the US' traditionally strong influence on Japan, one might have expected Suga to adopt crisis language when attending Joe Biden's Earth Day Climate Summit on April 22. However, Suga refrained from doing so despite declaring his intention to "lead global public opinion" (Suga, 2021, para. 1). Hence, the adoption of climate crisis language by the US under Joe Biden may have led more Cabinet members to address climate change in the Diet of Japan, but, so far, has not led to the Japanese government taking up similar climate securitisation language.

\section{Discussion and Conclusion}

This article set out to investigate the extent to which Japanese stakeholders are securitising global warming. The key finding is that securitisation actorsJapanese cities and climate NGOs, the MOE, and its minister Koizumi, as well as a multi-partisan group of parliamentarians-have established climate 
Table 2. Climate change framing by stakeholders in Japanese climate policy.

\begin{tabular}{|c|c|c|c|c|}
\hline Actor Category & Actor Name & Crisis Framing & Action Calls & Antagonism \\
\hline \multirow[t]{3}{*}{ Civil Society } & Kiko Network & $\begin{array}{l}\text { "Climate change-a threat to the } \\
\text { survival of our species" }\end{array}$ & $\begin{array}{l}\text { "Realisation of a zero-carbon } \\
\text { society and economy" }\end{array}$ & - \\
\hline & $\begin{array}{l}\text { Japan Climate } \\
\text { Initiative }\end{array}$ & $\begin{array}{l}\text { "Whether [the Paris Agreement] } \\
\text { goal will be achieved or not will } \\
\text { affect the survival of human }\end{array}$ & $\begin{array}{l}\text { "Expanding and accelerating } \\
\text { efforts toward a decarbonised } \\
\text { society" }\end{array}$ & - \\
\hline & & beings" & $\begin{array}{l}\text { "Working with each other and } \\
\text { with national governments to } \\
\text { accelerate their } \\
\text { nationally-determined processes } \\
\text { of transformation" }\end{array}$ & \\
\hline \multirow[t]{2}{*}{ City } & Kamakura & $\begin{array}{l}\text { "The global environment is } \\
\text { deteriorating due to climate } \\
\text { change" }\end{array}$ & $\begin{array}{l}\text { "Our goal is to achieve zero } \\
\text { emission of greenhouse gasses" }\end{array}$ & - \\
\hline & & $\begin{array}{l}\text { "We are calling for the } \\
\text { announcement of a 'climate } \\
\text { emergency declaration"” }\end{array}$ & & \\
\hline Parliament & $\begin{array}{l}\text { Diet of Japan } \\
\text { (Climate } \\
\text { Emergency } \\
\text { Declaration) }\end{array}$ & $\begin{array}{l}\text { "We share the global perception } \\
\text { that 'the global warming problem } \\
\text { now has exceeded the realm of } \\
\text { climate change and entered into } \\
\text { a situation of climate crisis"" }\end{array}$ & $\begin{array}{l}\text { "Strive for the immediate } \\
\text { realisation of a decarbonised } \\
\text { society, carry out a reorientation } \\
\text { of Japan's economic society" }\end{array}$ & - \\
\hline \multirow[t]{7}{*}{ Government } & $\begin{array}{l}\text { PM Suga } \\
\text { Speech }\end{array}$ & - & $\begin{array}{l}\text { "By } 2050 \text {, Japan will aim to } \\
\text { reduce greenhouse gas emissions } \\
\text { to net-zero" }\end{array}$ & - \\
\hline & & & $\begin{array}{l}\text { "Addressing climate change is no } \\
\text { longer a constraint on economic } \\
\text { growth, rather it will lead to } \\
\text { dynamic economic growth" by } \\
\text { "focusing on a virtuous cycle of } \\
\text { the economy and the } \\
\text { environment." }\end{array}$ & \\
\hline & & & (2020 Climate Ambition Summit) & \\
\hline & $\begin{array}{l}\text { Toshimitsu } \\
\text { Motegi }\end{array}$ & - & $\begin{array}{l}\text { "Making international } \\
\text { contributions in the field of } \\
\text { climate change has become the } \\
\text { most important task for our } \\
\text { foreign policy" }\end{array}$ & - \\
\hline & Tarō Kōno & - & $\begin{array}{l}\text { "Follow international trends" and } \\
\text { "implement the Paris } \\
\text { Agreement" }\end{array}$ & - \\
\hline & $\begin{array}{l}\text { Shinjirō } \\
\text { Koizumi }\end{array}$ & $\begin{array}{l}\text { "Climate change is now seen as } \\
\text { such a serious issue that abroad } \\
\text { it is even referred to as a climate } \\
\text { crisis" }\end{array}$ & $\begin{array}{l}\text { "Decarbonised society" } \\
\text { Lower coal-dependence "as } \\
\text { much as possible" }\end{array}$ & $\begin{array}{l}\text { The MOE and } \\
\text { the METI "are } \\
\text { not enemies" }\end{array}$ \\
\hline & & $\begin{array}{l}\text { "There is a growing perception in } \\
\text { all areas of Japan that climate } \\
\text { change has entered the phase of } \\
\text { a climate crisis" }\end{array}$ & & \\
\hline
\end{tabular}

Notes: Created by the authors based on the METI (2020), Diet of Japan (2020), Japan Climate Initiative (2018), Kamakura City Council (2019), Kiko Network (2021), MOE (2020), Suga (2020), as well as a keyword search of statements by Suga, Koizumi, Motegi, and Kōno in minutes of Diet of Japan debates during their ministerial period, or until March 4, 2021, available at Diet of Japan (2017-2021). 
securitisation as a new minor discourse. In doing so, they were clearly influenced by recent securitisation trends in international climate politics.

In contrast to the strong securitisation language used by UN Secretary-General António Guterres and climate activist Greta Thunberg, among others, Japanese securitisation actors, including civil society, pursue moderate securitisation by refraining from adopting combative language against specific culprits. One explanation for this might be the nature of civil society in Japan. According to Pekkanen (2003, p. 133), "it is hard for autonomous groups to become large and hard for large groups to be autonomous" due to the licensing process for so-called non-profit organisations, which includes considerable ministerial oversight and, therefore, expectations of compliance to the governmental line. Furthermore, "the LDP's [Liberal Democratic Party] return to power appears to have diminished the role of the strongest environmental advocates," including the removal of the head of the Kiko Network from policy advisory councils (Sofer, 2016, p. 14). Hence, the Kiko Network's choice of language might simply be a strategic decision to avoid further exclusion from policy discussions. As for the Japan Climate Initiative, it should be mentioned that it is part of a global network committed to working with governments rather than to lobby for stronger action.

Why did the MOE adopt a moderate securitisation discourse? Most crucially, the MOE's ability to push for stronger climate action depends on its ability to convince the METI to shift Japan's energy policy, since the majority of Japan's greenhouse gas emissions comes from the energy sector. Hence, non-antagonism most likely represents a strategic decision by the MOE to avoid antagonising the METI and increase the chances of convincing it to adopt stronger climate policies.

While the efforts of securitisation actors have led to the establishment of climate securitisation as a new minor discourse, they have so far failed to garner support from the prime minister and the METI. These findings are in line with previous findings of the importance of prime ministerial involvement to bring about change in Japan's METI-dominated climate discourse and policy (Kameyama, 2017; Tiberghien \& Schreurs, 2010; Watanabe, 2011). Rather than adopting climate securitisation language, Suga (2020) repeated the language in the 2019 long-term strategy under the Paris Agreement almost word by word at the 2020 Climate Ambition Summit-as did the METI and MOFA papers. The analysis has revealed that the framing of climate change mitigation as an opportunity for economic growth has apparently replaced the former hegemonic METI-sponsored framing of climate change action as an economic burden. The broad adoption of the economic opportunity framing, introduced by Suga's predecessor Shinzō Abe, further suggests that prime ministerial support is crucial for a new discourse to become hegemonic in Japan.

Comparing Japan to the "climate crisis" language used by Joe Biden and the $\mathrm{EU}$ in its updated national determined contributions for the Paris Agreement, it becomes clear that Japan is lagging international developments. Japan's position as a leader or laggard has previously been explained by the relative weight attributed to the conflicting goals of economic growth, international contribution, and environmental protection (Hattori, 2007). Even though the Suga government stresses climate change mitigation as an opportunity for economic growth and seeks to exhibit global leadership, the government is far from leading the global climate change discourse-or international climate politics for that matter. Considering Schoppa's (1993, p. 383) finding that foreign pressure will "produce the most positive results when these strategies resonate with domestic politics," the government's avoidance of the term "climate crisis" can be explained by its insistence on promoting coal, historically the biggest contributor to global warming.

In conclusion, the Japanese government has yet to walk the walk after talking the international contribution talk. Hitherto lacklustre greenhouse gas reduction targets under the Paris Agreement and support for fossil fuel projects garnered Japan two unflattering Fossil of the Day Awards at the 2019 UN Climate Summit, which the Climate Action Network awards to countries it regards as laggards. Suga's predecessor Shinzō Abe was further denied the chance to speak at the UN Climate Action Summit in September 2019, which was designed to showcase climate leaders' actions. These setbacks notwithstanding, the emergence of a moderate securitisation discourse has at least created the conditions of possibility for more comprehensive and drastic climate policies going forward. The extent to which this opening for change in Japan will be pursued is an important object for future research.

\section{Acknowledgments}

We would like to thank the anonymous reviewers for their comments and suggestions. We also thank the thematic issue editor, Yasuko Kameyama, for valuable feedback on an earlier article draft presented at the 2020 Annual Workshop of the German Association for Social Science Research on Japan. This open-access publication received financial support from the Chair for Environmental and Climate Policy at the Technical University of Munich.

\section{Conflict of Interests}

The authors declare no conflict of interest.

\section{References}

Balzacq, T., Léonard, S., \& Ruzicka, J. (2016). 'Securitization' revisited: Theory and cases. International Relations, 30(4), 494-531. https://doi.org/10.1177/ 0047117815596590 
Biden, J. (2021). Remarks by President Biden before signing executive actions on tackling climate change, creating jobs, and restoring scientific integrity [Speech transcript]. The White House. https://www. whitehouse.gov/briefing-room/speeches-remarks/ 2021/01/27/remarks-by-president-biden-beforesigning-executive-actions-on-tackling-climatechange-creating-jobs-and-restoring-scientificintegrity

Busby, J. (2019). The field of climate and security: A scan of the literature. The Social Science Research Council. https://www.ssrc.org/publications/view/the-fieldof-climate-and-security-a-scan-of-the-literature

Buzan, B., Waever, O., \& de Wilde, J. (1998). Security: A new framework for analysis. Lynne Rienner Publishers.

Climate Emergency Declaration Campaign. (2020). Climate emergency declarations in 1,788 jurisdictions and local governments cover 820 million citizens. Climate Emergency Declaration. https://climate emergencydeclaration.org/climate-emergencydeclarations-cover-15-million-citizens

Detraz, N., \& Betsill, M. M. (2009). Climate change and environmental security: For whom the discourse shifts. International Studies Perspectives, 10(3), 303-320.

de Wilde, J. H. (2008). Environmental security deconstructed. In H. G. Brauch, N. C. Behera, B. Chourou, P. Dunay, J. Grin, P. Kameri-Mbote, P. H. Liotta, C. Mesjasz, \& Ú. O. Spring (Eds.), Hexagon series on human and environmental security and peace: Vol. 3. Globalization and environmental challenges: Reconceptualizing security in the 21st century (pp. 595-602). Springer.

Diet of Japan. (2017-2021). Kokkai kaigiroku kensaku shisutemu [Diet of Japan minutes search system]. https://kokkai.ndl.go.jp/\#

Diet of Japan. (2020). Kikō hijō jitai sengen [Climate emergency declaration]. https://www.sangiin.go.jp/ japanese/gianjoho/ketsugi/203/201120-1.html

Doty, R. L. (1993). Foreign policy as social construction: A post-positivist analysis of US counterinsurgency policy in the Philippines. International Studies Quarterly, 37(3), 297-320.

Eckstein, D., Künzel, V., \& Schäfer, L. (2021). Global climate risk index 2021: Who suffers most from extreme weather events? Weather-related loss events in 2019 and 2000 to 2019. Germanwatch. https:// germanwatch.org/sites/germanwatch.org/files/ Global\%20Climate\%20Risk\%20Index\%202021_1.pdf

Eckstein, D., Künzel, V., Schäfer, L., \& Winges, M. (2019). Global climate risk index 2020: Who suffers most from extreme weather events? Weather-related loss events in 2018 and 1999 to 2018. Germanwatch. https://www.germanwatch.org/en/17307

Elliott, L. (2012). Regionalizing environmental security in Asia. In M. Beeson \& R. Stubbs (Eds.), Routledge handbook of Asian regionalism (300-312). Routledge.
EU. (2020). Update of the NDC of the European Union and its member states. https://www4.unfccc. int/sites/NDCStaging/Pages/Party.aspx?party=EUU\& prototype $=1$

Guterres, A. (2019). Remarks at 2019 climate action summit: 23 September 2019, António Guterres. UN. https://www.un.org/sg/en/content/sg/speeches/ 2019-09-23/remarks-2019-climate-action-summit

Hagström, L., \& Hanssen, U. (2015). The North Korean abduction issue: Emotions, securitisation and the reconstruction of Japanese identity from 'aggressor' to 'victim' and from 'pacifist' to 'normal.' The Pacific Review, 28(1), 71-93. https://doi.org/ 10.1080/09512748.2014.970043

Hattori, T. (2007). The rise of Japanese climate change policy: Balancing the norms economic growth, energy efficiency, international contribution and environmental protection. In M. E. Pettenger (Ed.), Global environmental governance. The social construction of climate change: Power, knowledge, norms, discourses (pp. 75-97). Taylor \& Francis.

Howarth, D. R. (2000). Discourse. Concepts in the social sciences. Open University Press.

Imada, Y., Watanabe, M., Kawase, H., Shiogama, H., \& Arai, M. (2019). The July 2018 high temperature event in Japan could not have happened without human-induced global warming. SOLA, 15A, 8-12. https://doi.org/10.2151/sola.15A-002

Incerti, T., \& Lipscy, P. Y. (2018). The politics of energy and climate change in Japan under Abe: Abenergynomics. Asian Survey, 58(4), 607-634. https://doi. org/10.1525/as.2018.58.4.607

Intergovernmental Panel on Climate Change. (2014). Climate change 2014 synthesis report summary for policymakers.

Intergovernmental Panel on Climate Change. (2018). Summary for policymakers: Global warming of $1.5^{\circ} \mathrm{C}$ (IPCC special report).

Japan Climate Initiative. (2018). Launch of the Japan climate initiative (JCl) and invitation for participation. https://docplayer.net/89239334-Launch-of-thejapan-climate-initiative-jci-and-invitation-forparticipation.html

Kamakura City Council. (2019). Decision regarding climate emergency declaration [Kikō hijō jitai sengen ni kan suru ketsugi]. https://www.city.kamakura. kanagawa.jp/gikai/documents/gikaigian0905.pdf

Kameyama, Y. (2002). Climate change and Japan. AsiaPacific Review, 9(1), 33-44. https://doi.org/10.1080/ 13439000220141578

Kameyama, Y. (2017). Climate change policy in Japan: From the 1980s to 2015 (Vol. 5). Routledge.

Kameyama, Y. (2021). Climate change policy: Can new actors affect Japan's policy-making in the Paris agreement era? Social Science Japan Journal, 24(1), 67-84. https://doi.org/10.1093/ssjj/jyaa051

Kameyama, Y., \& Ono, K. (2021). The development of climate security discourse in Japan. Sustainabil- 
ity Science, 16(1), 271-281. https://doi.org/10.1007/ s11625-020-00863-1

Kiko Network. (2021). Our mission. https://www.kikonet. org/eng/about-us-en/our-mission

Koppenborg, F. (2018). Remodelling Japan's climate policy. East Asia Forum. https://www.eastasiaforum. org/2018/12/05/remodelling-japans-climate-policy

Koppenborg, F. (2021). Nuclear restart politics: How the 'nuclear village' lost policy implementation power. Social Science Japan Journal, 24(1), 115-135. https:// doi.org/10.1093/ssjj/jyaa046

McDonald, M. (2013). Discourses of climate security. Political Geography, 33, 42-51. https://doi.org/ 10.1016/j.polgeo.2013.01.002

METI. (2020). Enerugī ni kan suru nenji hōkoku [Annual report on energy]. Agency for Natural Resources and Energy. https://www.enecho.meti.go.jp/about/ whitepaper

MOE. (2020). Reiwa 2 nen-ban kankyō hakusho, junkangata hakusho, seibutsu tayō hakusho [Annual report on the environment, the sound material-cycle society and biodiversity in Japan 2020]. https://www.env.go. jp/policy/hakusyo/index.html

MOFA. (2020). Gaikō seisho 2020 [Diplomatic blue book 2020]. https://www.mofa.go.jp/mofaj/fp/pp/ page22_1003299.html

Pekkanen, R. (2003). Molding Japanese civil society: State-structured incentives and the patterning of civil society. In F. J. Schwartz \& S. J. Pharr (Eds.), The state of civil society in Japan (pp. 116-134). Cambridge University Press.

Rear, D., \& Jones, A. (2013). Discursive struggle and contested signifiers in the arenas of education policy and work skills in Japan. Critical Policy Studies, 7(4), 375-394. https://doi.org/10.1080/19460171. 2013.843469

Schoppa, L. J. (1993). Two-level games and bargaining outcomes: Why gaiatsu succeeds in Japan in some cases but not others. International Organization, 47(3), 353-386. https://doi.org/10.1017/ S0020818300027995

Schulze, K. (2016). Japan's new assertiveness: Institutional change and Japan's securitization of China. International Relations of the Asia-Pacific, 18(2), 221-247. https://doi.org/10.1093/irap/lcw018
Sofer, K. (2016). Climate politics in Japan: The impacts of public opinion, bureaucratic rivalries, and interest groups on Japan's environmental agenda. Sasakawa Peace Foundation USA. https://spfusa.org/ wp-content/uploads/2016/05/Sofer-ClimatePolitics-in-Japan.pdf

Suga, Y. (2020). Speech by Prime Minister Suga at Climate Ambition Summit: (12 December 2020) [Speech Transcript]. The Mission of Japan to the European Union. https://www.eu.emb-japan.go.jp/files/ 100125772.pdf

Suga, Y. (2021, April 22). Press conference 22.04.2021. Kantei. https://www.kantei.go.jp/jp/99_suga/ statement/2021/0422kaiken.html

Thunberg, G. (2019a). "Our house is on fire": Greta Thunberg, 16, urges leaders to act on climate [Speech transcript]. The Guardian. https://www.theguardian. com/environment/2019/jan/25/our-house-is-onfire-greta-thunberg16-urges-leaders-to-act-onclimate

Thunberg, G. (2019b). Transcript: Greta Thunberg's speech at the UN Climate Action Summit [Speech transcript]. National Public Radio. https://text.npr. org/763452863

Tiberghien, Y., \& Schreurs, M. (2010). Climate leadership, Japanese style: Embedded symbolism and post-2001 Kyoto protocol politics. In K. Harrison \& L. M. Sundstrom (Eds.), American and comparative environmental policy. Global commons, domestic decisions: The comparative politics of climate change (pp. 139-168). MIT Press.

UN. (2015). Paris agreement. https://unfccc.int/sites/ default/files/english_paris_agreement.pdf

UN Security Council. (2007). Security council holds firstever debate on impact of climate change on peace, security: Hearing over 50 speakers. https://www.un. org/press/en/2007/sc9000.doc.htm

Watanabe, R. (2011). Climate policy changes in Germany and Japan: A path to paradigmatic policy change (Vol. 41). Taylor \& Francis.

Weldes, J., \& Saco, D. (1996). Making state action possible: The USA and the discursive construction of 'the Cuban problem,' 1960-1994. Journal of International Studies, 25(2), 361-395.

\section{About the Authors}

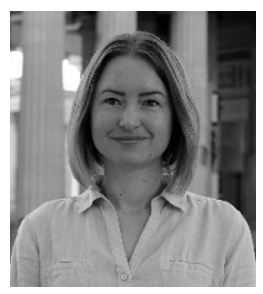

Florentine Koppenborg is a postdoctoral fellow at the Bavarian School of Public Policy at the Technical University of Munich. Her research interests are within the area of energy and climate policy, particularly energy transitions (energiewende) and interactions with climate policy. She has authored several peer-reviewed articles and book chapters on Japan's nuclear energy and climate policy. 


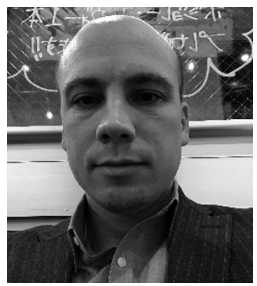

Ulv Hanssen is an associate professor at Soka University's Faculty of Law. His research focuses on Japan's security policy and international relations, as well as North Korea-related developments. 